\title{
The Optic Tract and Tectal Ablation Influence the Composition of Neurofilaments in Regenerating Optic Axons of Xenopus laevis
}

\author{
Yangu Zhao and Ben G. Szaro \\ Department of Biological Sciences and the Neurobiology Research Center, University at Albany, State University of \\ New York, Albany, New York 12222
}

\begin{abstract}
Neurofilaments have been proposed to regulate axonal stability and diameter through changes in number and subunit composition. We have found that pathway and target innervation directly influence the molecular composition of neurofilaments within regenerating optic axons of Xenopus laevis. Immunocytochemistry was used to examine neurofilaments within two abnormal visual pathways. The first was an aberrant, transient retinoretinal projection, which formed when some axons entered the contralateral optic nerve at the chiasm. The second was formed by regenerating axons deprived of their normal targets by surgical ablation of both optic tecta. Distal to an orbital nerve crush, the neurofilament proteins NF-L, NF-M, NF-H, and XNIF disappear from degenerating fibers. In normally regenerating axons, these neurofilament proteins emerge in a progression reminiscent of development. In the aberrant retinoretinal projection, levels of XNIF, NF-L, and -M remained lower than in normally regenerating axons, whereas NF-H and a phosphorylated form of NF-M were undetectable for at least $35 \mathrm{~d}$ after nerve crush. Normally, these two latter forms reappear between 15 and $21 \mathrm{~d}$ after surgery. Thus, this transient, incorrect axonal projection expressed neurofilaments in a very different pattern from correctly regenerating axons. In tecta-ablated frogs, staining of phosphorylation independent epitopes of XNIF, NF-L, and $-M$ increased normally after axons entered the tract, but that of NF-H and phosphorylated NF-M remained low for at least $42 \mathrm{~d}$ after axotomy. Thus, separate parts of the visual pathway influence the complexity of neurofilaments.
\end{abstract}

[Key words: retinoretinal projection, axonal regeneration, retinotectal projection, neurofilaments, axon-target interactions, Xenopus laevis]

Pathways and targets of growing axons provide cues that influence the expression of specific axonal proteins (e.g., Benowitz et al., 1981; Perry et al., 1990; Hieber et al., 1992). Effects on cytoskeletal proteins are especially interesting because of the cytoskeleton's role in cell motility and in establishing axonal

Received Nov. 8, 1994; revised Jan. 31, 1995; accepted Feb. 3, 1995.

We thank Dr. Virginia Lee (University of Pennsylvania) for the H053 and DP- 1 antibodies, and Dr. Lawrence Charnas (NIH) for the LC2 antiserum used in this study. In addition, we thank Dr. Jon Jacklet for the use of his Nomarski optics; Drs. Suzannah Tieman, Gregory Lnenicka, and John Schmidt for comments on the manuscript; and Drs. Tieman and Schmidt for technical and scientific advice. This work was supported by NIH Grant R29 NS30682 to Ben Szaro.

Correspondence should be addressed to Ben G. Szaro, Biology, SUNY-Albany, 1400 Washington Avenue, Albany, NY 12222.

Copyright (C) 1995 Society for Neuroscience $0270-6474 / 95 / 154629-12 \$ 05.00 / 0$ shape and caliber. The axonal cyloskeleton comprises three major polymers: microfilaments, microtubules, and neurofilaments. Whereas microfilaments and microtubules generate motile forces, the neurofilaments are purely structural, functioning primarily to consolidate the axon and to enhance axonal caliber. Nevertheless, neurofilaments are also dynamic, which has implications for neuronal plasticity. For example, during axonal development, neurotilament proteins are expressed and subsequently phosphorylated in a stereotypic progression that reflects axonal maturation (Shaw and Weber, 1982; Pachter and Liem, 1984; Dahl and Bignami, 1986; Dahl et al., 1986; Carden et al., 1987; Szaro et al., 1989; Kaplan et al., 1990; Charnas et al., 1992; Fliegner et al., 1994). Newly formed neuritic processes have few, if any, neurofilaments. Actively elongating vertebrate axons contain a low molecular weight neurofilament protein (e.g., NF$\mathrm{L}, \mathrm{XNIF}$, peripherin, or $\alpha$-internexin) often accompanied by the middle molecular weight neurofilament protein, NF-M. As axons mature, levels of these neurofilament proteins increase, and the highest molecular weight neurofilament protein, NF-II, emerges. Also, during axonal maturation the carboxyl terminal domains of both NF-M and NF-H are progressively phosphorylated at repeated lysine-serine-proline residues. This phosphorylation accompanies a deceleration in slow axonal transport and an increase in axonal caliber. In mammals and birds, this pattern also occurs in regenerating peripheral axons (Goldstein et al., 1988; Dahl et al., 1989; Oblinger et al, 1989). However, after axotomy of centrally projecting mammalian axons, which are incapable of regenerating effectively, neurofilament protein expression varies little from mature axons (Goldstein et al., 1987; Oblinger and Lasek, 1988; Mikucki and Oblinger, 1991). This is, in part, due to interactions between axotomized axons and CNS glia, which inhibit regrowth (Liuzzi and Tedeschi, 1992).

Previously, we showed that regenerating optic axons of the frog, Xenopus laevis, also exhibit a progressive pattern of neurofilament protein expression (Zhao and Szaro, 1994). After axotomy, epitopes of two low molecular weight neurofilament proteins, XNIF and Xenopus NF-L, and a phosphorylation independent epitope of NF-M (NF-M/ind) first reappear as axons approach the optic chiasm. Once axons enter the optic tract, the expression of these neurofilament proteins continues to increase. NF-H and phosphorylated forms of NF-M (NF-M/P) appear only after axons arrive at the optic tectum, the primary visual center of the frog. This correlation suggested that regenerating Xenopus optic axons might coordinate the progressive maturation of their neurofilaments with axonal regrowth through cues encountered along the visual pathway.

Here, we have tested this hypothesis by observing the neu- 

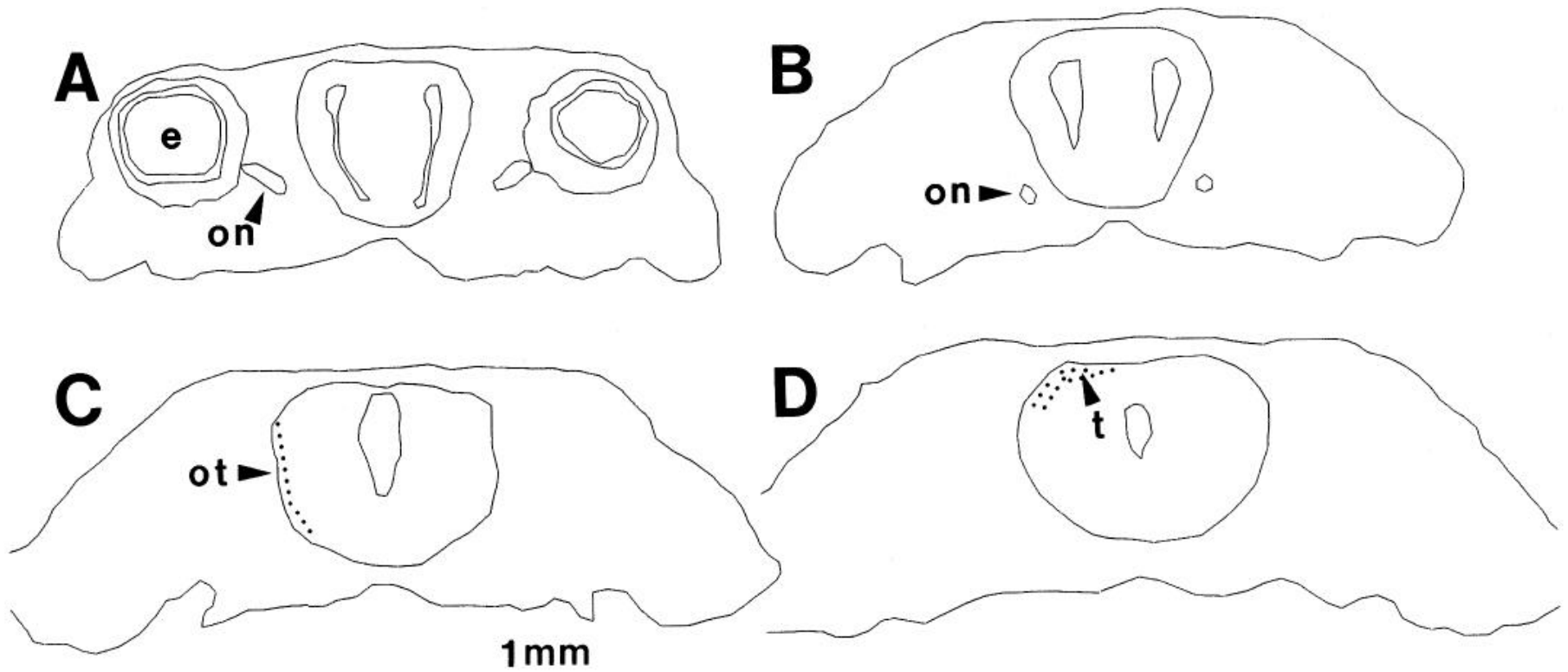

Figure 1. Camera lucida drawings of representative sections showing the optic pathway at progressively more caudal levels in sections cut transversely through the head. $A$, Section at the level of the proximal optic nerve $(o n)$ near its exit from the eye $(e)$. $B$, Section illustrating the optic nerve (on) approximately midway between the eye and the chiasm. $C$, Section illustrating the location of the optic tract (ot), which runs along the surface of the brain at the arrowhead. $D$, Section cut at the level of the rostral optic tectum $(t)$.
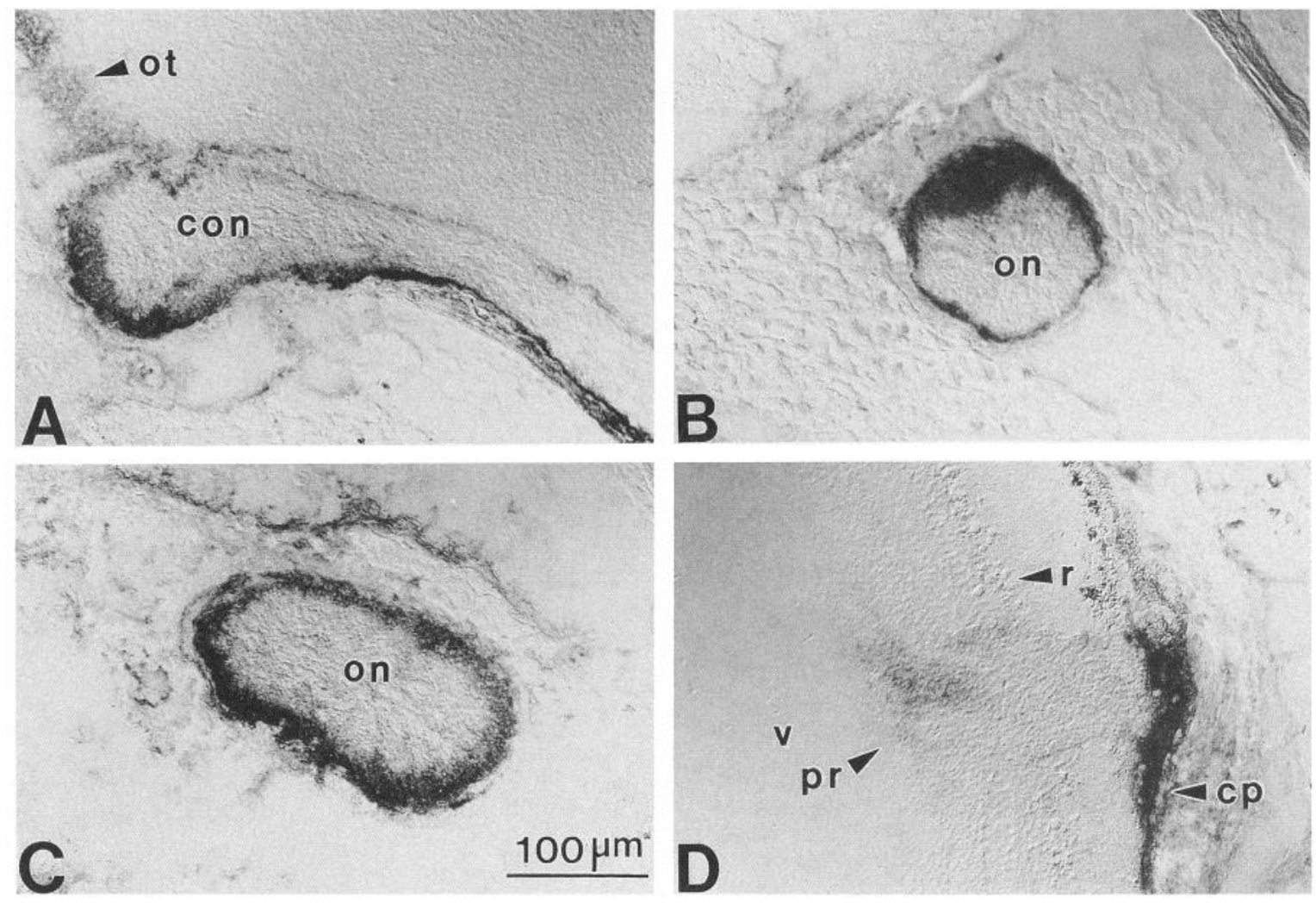

Figure 2. Regenerating optic axons that have followed an anomalous pathway into the contralateral optic nerve. The regenerating axons were labeled by injection of WGA-HRP into the eye from which they originated. Sections were cut transversely and are viewed here under Nomarski optics. In all panels, lateral is to the left; dorsal is up. A, Labeled retinoretinal axons coursing through the contralateral chiasmatic optic nerve (con) just past the optic chiasm. The optic chiasm is located to the right of the edge of the panel. The arrowhead at ot indicates labeled optic axons projecting normally into the contralateral optic tract (ot). $B$, Labeled regenerating optic axons within the contralateral optic nerve (on), halfway between the eye and the optic chiasm (see Fig. $1 B$ for orientation). $C$, Labeled regenerating optic axons within the proximal region of the contralateral optic nerve (on) (see Fig. $1 A$ for orientation). D, Labeled regenerating optic axons entering the contralateral eye. The labeled axons are seen within the optic nerve head at the papilla of the retina $(p r)$ and extending into the neighboring retina. The vitreous $(v)$ of the eye is to the left. The choroidal pigment $(c p)$ is naturally black and does not represent WGA-HRP labelling. Scale bar in $C$ applies to all panels. 

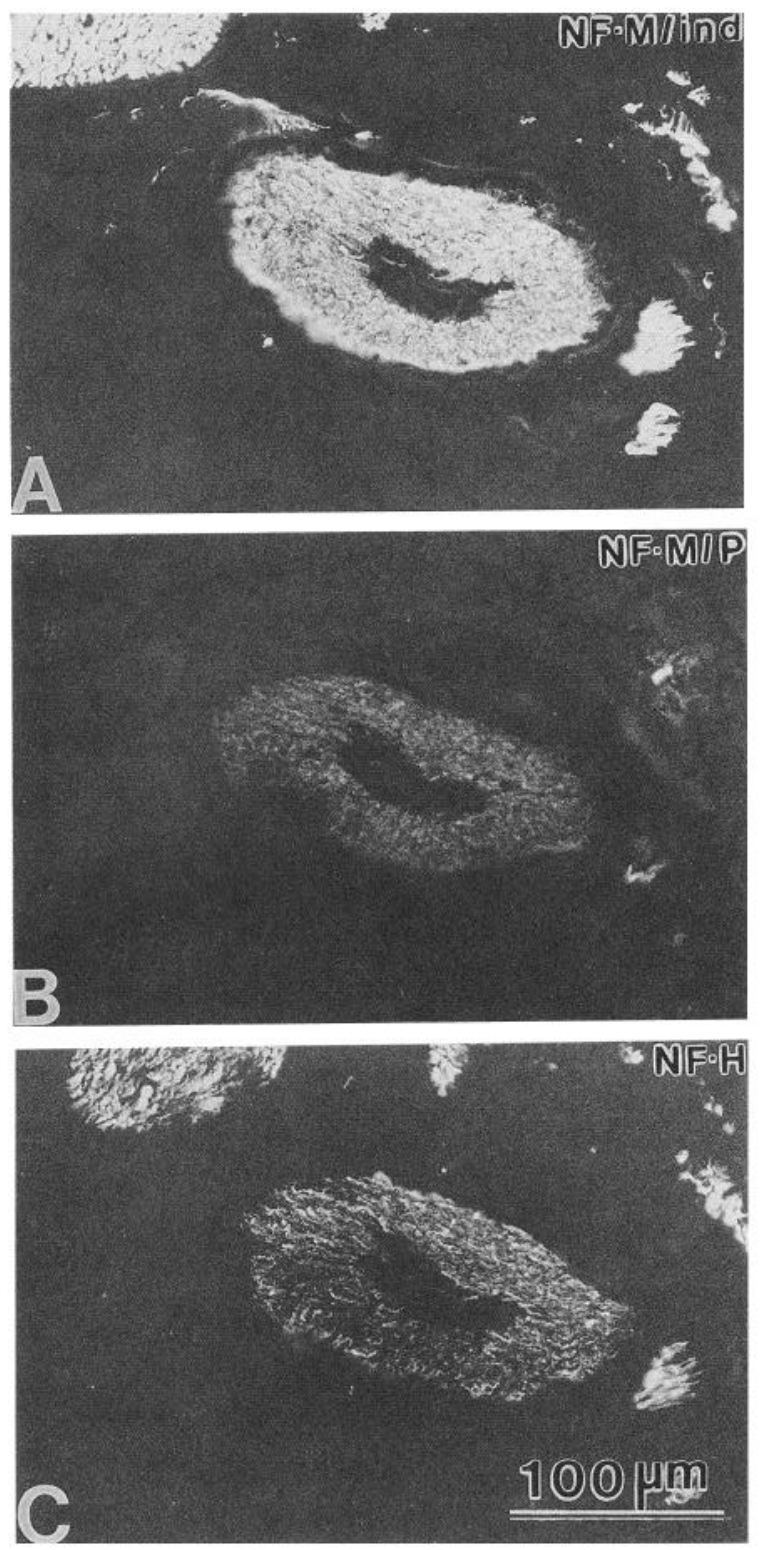

Figure 3. Regenerating optic axons in a crushed optic nerve, 5 weeks after surgery. Axons were labeled by immunofluorescent staining with antibodies directed against NF-M/ind (XC10C6, $A$ ), NF-M/P (H053, $B$ ), and NF-H (DP-1, C). The sections were taken at approximately the same level as shown in Figure $1 B$. Scale bar in $C$ is for all panels.

rofilament composition of regenerating optic axons of two aberrant projections. In the first case, regenerating axons entered the contralateral optic nerve and invaded the contralateral retina. This retinoretinal projection forms during optic nerve regeneration in several species of frogs, including Xenopus laevis (Fawcett, 1985), Hyla moorei (Tennant et al., 1993), and Rana pipiens (Bohn and Stelzner, 1981a-c). As demonstrated in Rana, this projection comprises misdirected axons rather than collateral branches of normally projecting axons (Bohn and Stelzner, 1981b). In forming an aberrant retinoretinal projection, these axons fail to encounter the optic tract or the tectum. In the second case, both optic tecta were surgically removed. This deprived normally regenerating optic axons of their usual targets, without significantly altering the optic tract. In the first case, retinoretinal axons expressed reduced levels of all neurofilament epitopes. In the second, axons deprived of their tectal targets failed to express normal levels of NF-H and phosphorylated NF-M.

\section{Materials and Methods}

Primary antibodies. Xenopus laevis neurofilament proteins were detected by antibodies previously characterized on Western blots of Xenopus laevis optic nerve (Zhao and Szaro, 1994), brain and spinal cord (Szaro and Gainer, 1988; Szaro et al., 1989; Wetzel et al., 1989; Charnas et al., 1992). Xenopus laevis has two low molecular weight neurofilament proteins, NF-L (Szaro and Gainer, 1988) and XNIF (Charnas et al., 1992). A phosphorylation independent epitope of Xenopus laevis NF-L was detected by the monoclonal antibody, XC5D10, made from mice immunized with intermediate filament extracts of adult Xenopus nervous system (Szaro and Gainer, 1988; Charnas et al., 1992). XNIF was detected by the rabbit serum, LC2, made against a synthetic peptide derived from the amino acid sequence of XNIF (Charnas et al., 1992). A phosphorylation independent epitope of Xenopus NF-M (NF-M/ind) was detected by the monoclonal antibody, XC10C6, which originated from the same fusion as XC5D10 (Szaro and Gainer, 1988). A phosphorylated epitope of NF-M (NF-M/P) was detected by a monoclonal antibody, H053, derived from rats immunized with mammalian neurofilaments (Lee et al., 1988). In Xenopus, the H053 epitope is removed by extensive treatment of NF-M with bacterial alkaline phosphatase (Szaro et al., 1989); and in mammals this epitope consists of repeatedly phosphorylated lysine-serine-proline residues within the carboxyl terminal domain of NF-M (Lee et al., 1988). Xenopus NF-H shares some antigenic sites with mammalian NF-H (Szaro and Gainer, 1988; Wetzel et al., 1989; Zhao and Szaro, 1994), including a nonphosphorylated epitope that was detected by the monoclonal antibody, DP-1, from rats immunized with mammalian neurofilaments (Lee et al., 1986).

Animals and surgery. Periodic albino Xenopus laevis frogs (Hoperskaya, 1975; Tompkins, 1977) younger than 3 months postmetamorphosis were used in three groups, A, B, and C. These frogs were reared in our own laboratory from the same stock as those used in previous studies on neurofilaments in optic nerve development (Szaro et al., 1989) and regeneration (Zhao and Szaro, 1994). Frogs from groups B and $\mathrm{C}$ were co-reared siblings. For all groups, after frogs were anesthetized by immersion in $0.1 \%$ tricaine methanesulfonate (3-aminobenzoate ethyl ester; Sigma, St. Louis, MO), the right optic nerve of each was crushed at the orbit (Zhao and Szaro, 1994). The left optic nerve remained intact.

Group A, which was used to examine retinoretinal projections, received no further surgery. Groups B (tecta-ablated frogs) and C (shamoperated controls) were used in parallel to study target effects on neurofilament expression. Immediately after the nerve was crushed, the overlying cartilaginous skull and meninges of groups $\mathrm{B}$ and $\mathrm{C}$ were retracted, exposing both optic tecta. In group B, the optic tecta were bilaterally removed by gentle vacuum aspiration. In group $\mathrm{C}$, the tecta remained intact. Afterwards, skull flaps were replaced, and the frogs were kept for $6 \mathrm{~d}$ in moist chambers containing sulfadiazine (Sigma, St. Louis, MO) to guard against infection. Later, they were returned to conventional plastic aquaria. For each tecta-ablated frog, the etfect of the surgery was verified on frozen histological sections cut from the optic tecta and stained with cresyl violet.

Preparation of frozen histological sections. Frogs were anesthetized as before and sacrificed by decapitation. After the lower mandibles were removed, the heads were embedded in OCT compound (Miles, Elkhart, IN), frozen immediately on dry ice and stored at $-70^{\circ} \mathrm{C}$. Serial transverse frozen sections, $10 \mu \mathrm{m}$ thick, were cut beginning at the eyes and extending through the optic tecta. Adjacent sections were mounted on successive gelatinized slides and stored at $-20^{\circ} \mathrm{C}$. For orientation, camera lucida drawings of representative sections along the optic pathway are shown at low magnification in Figure 1. These drawings will be referred to in the figure legends to note the origin and orientation of the photomicrographs.

Tracing of regenerating axons with WGA-HRP. Regenerating optic axons were labeled by wheat germ agglutinin conjugated to horseradish peroxidase (WGA-HRP) as described previously (Zhao and Szaro, 1994). A volume of $0.1 \mu \mathrm{l}$ of a $5 \%$ solution of WGA-HRP (Sigma, St. Louis, MO) was pressure-injected through a glass micropipette into the vitreous of the eye with the crushed nerve. Animals were sacrificed after the optimal survival time of $30 \mathrm{hr}$. For analysis, frozen sections were first fixed briefly in cold absolute methanol, followed by immer- 

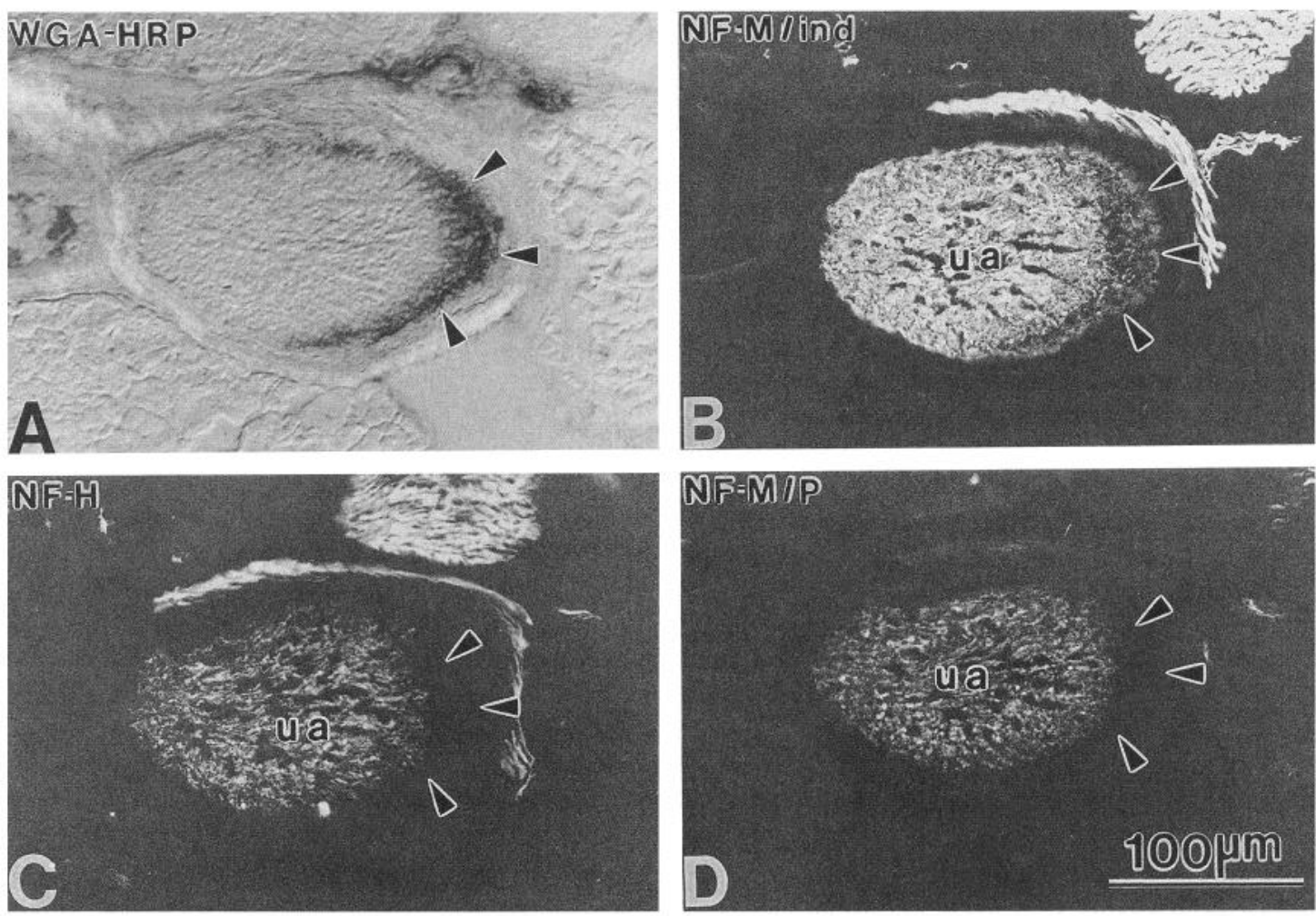

Figure 4. Regenerating optic axons misrouted into the contralateral optic nerve, 5 weeks after surgery, labeled either by intraocular injection of WGA-HRP $(A)$ or by immunofluorescent staining with antibodies directed against various forms of the neurofilament proteins $(B-D)$. The aberrantly projecting axons are indicated by the arrowheads in all panels. A, WGA-HRP labeled misprojected regenerating optic axons within the contralateral optic nerve, visualized with Nomarski optics. $B$, The section adjacent to $A$, stained with the antibody (XC10C6) directed against NF-M/ind and visualized with the fluorescence microscope. The staining of the misprojecting axons was less intense than that of the normal uninjured axons (ua), which are projecting normally through their own optic nerve. $C$, The next section adjacent to $B$, stained with the antibody (DP-1) directed against nonphosphorylated NF-H. No immunoreactivity was detectable in the misprojecting axons. $D$, The next section adjacent to $C$, stained with the antibody (H053) directed against NF-M/P. Again, no immunoreactivity was detected in the misprojecting axons. The sections were taken at approximately the same level as shown in Figure $1 B$, and are from the same sections as those shown in Figure 3 . Scale bar in $D$ is for all panels.

sion in $1 \%$ glutaraldehyde/ $2 \%$ sucrose in $0.1 \mathrm{~m}$ sodium phosphate buffer (pH 7.4). After extensive washes in tris buffered saline (TBS, $\mathrm{pH} 7.4$ ), the WGA-HRP was detected by immunoperoxidase staining with an anti-horseradish peroxidase rabbit antiserum (Sigma, St. Louis, MO) diluted 1:5,000 (Szaro et al., 1990; Zhao and Szaro, 1994).

Immunocytochemistry. For immunofluorescent staining of neurofilament proteins, frozen sections serially adjacent to those assayed for WGA-HRP were fixed in ice-cold absolute methanol. (To reduce experimental variation, slides from tecta-ablated and sham-operated control frogs were processed in parallel.) Slides were blocked in $10 \%$ calf serum/TBS (Sigma, St. Louis, MO) and incubated overnight in primary antibody. Primary antibodies were diluted in blocking solution as follows: XC10C6, ascites fluid diluted 1:5,000; H053 and X5D10, undiluted hybridoma supernatants; DP-1, hybridoma supernatant diluted 1:10; LC-2, rabbit serum diluted 1:1000. Controls for nonspecific immunostaining are described elsewhere (Szaro and Gainer, 1988; Szaro et al., 1989; Charnas et al., 1992; Zhao and Szaro, 1994). After extensive washes in TBS, slides were placed in appropriate biotinylated secondary antibodies $(2.5 \mu \mathrm{g} / \mathrm{ml}$; Kirkegaard and Perry, Gaithersburg, MD) for $4 \mathrm{hr}$, and then in avidin-rhodamine $(1: 400$, Vector Laboratories, Burlingame, CA) for an additional $2 \mathrm{hr}$. They were then washed and mounted in glycerol/para-phenylenediamine. Immunofluorescent sections were observed on a Leitz Laborlux $\mathrm{S}$ compound microscope through an N2 filter cube, and photographed with a Wild/Leitz MPS46 camera. Photographic exposure times were fixed after metering from the uncrushed nerve.

\section{Results}

Previously, we defined the pattern of reemergence of neurofilament epitopes during the regeneration of retinal axons (Zhao and
Szaro, 1994). That work led to the hypothesis that the neurofilament composition of regenerating optic axons might be influenced by cues encountered along the visual pathway. We have now tested this hypothesis directly by examining the neurofilament composition of misrouted regenerating axons in two separate circumstances. The first circumstance involved axons of an aberrant retinoretinal projection that formed within the contralateral nerve; the second circumstance consisted of axons deprived of their normal targets by surgical ablation of both optic tecta. In both cases, the regenerating axons were labeled by WGA-HRP. The neurofilament composition of these axons was then revealed in adjacent sections by immunocytochemistry with antibodies to Xenopus laevis neurofilament proteins.

\section{Neurofilament proteins in the axons of the retinoretinal projection}

The aberrant retinoretinal projection forms routinely during optic nerve regeneration in several species of frogs, including Xenopus laevis (Fawcett, 1985), Rana pipiens (Bohn and Stelzner, 1979, 1981a-c) and Hyla moorei (Humphrey and Beazley, 1985). These axons regenerate normally within their own optic nerve, but at the chiasm, they enter the contralateral optic nerve instead of the optic tract. First, we identified the retinoretinal projection with WGA-HRP used as an anterograde tracer. After an orbital optic nerve crush, animals were examined for the pres- 

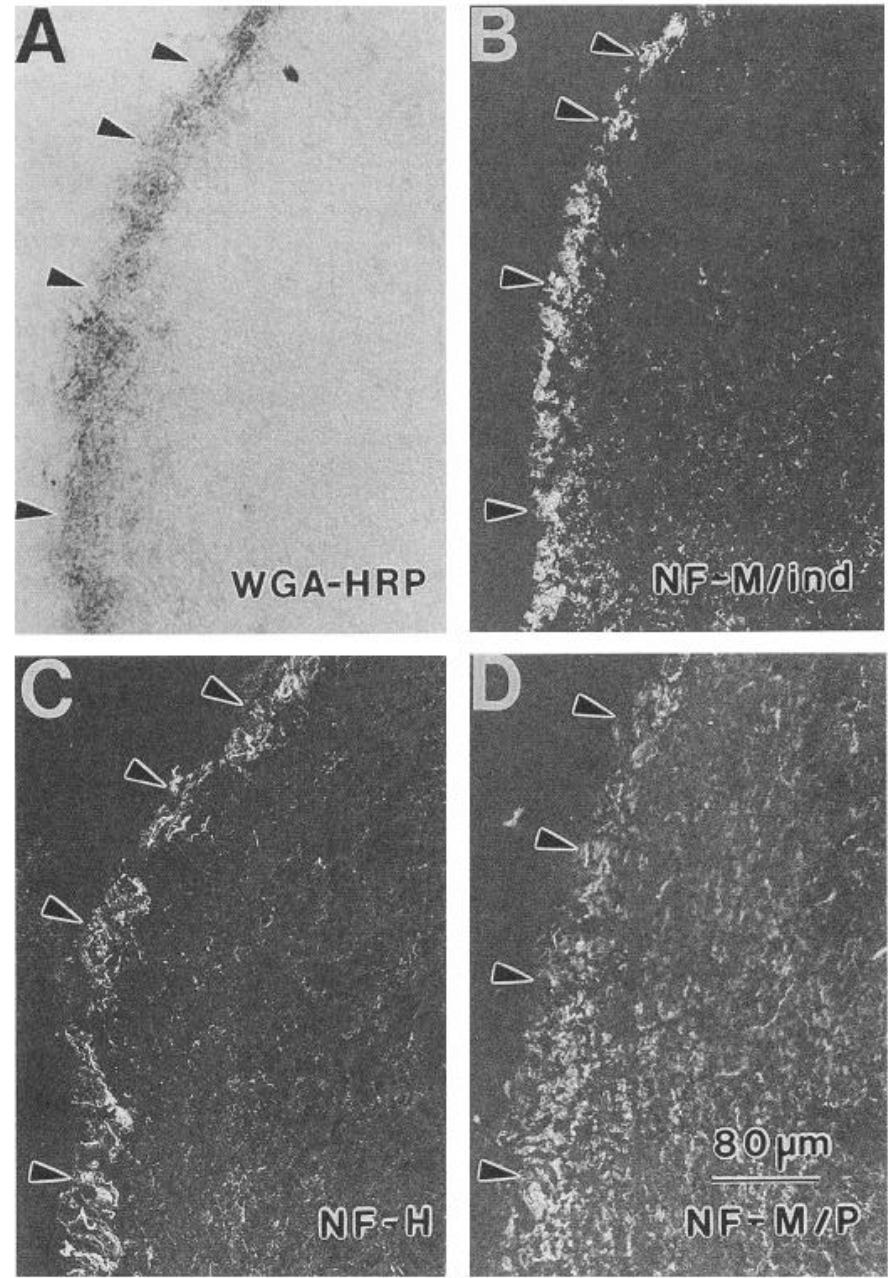

Figure 5. Regenerating optic axons that have followed a normal pathway into the contralateral optic tract, 4 weeks after a nerve crush. The regenerating axons are indicated by the arrowheads in all panels. A, Regenerating axons labeled with intraocularly injected WGA-HRP and viewed under Nomarski optics. $B-D$, Sections adjacent to that in $A$, immunostained with antibodies directed against nonphosphorylated epitopes of NF-M $(B)$, NF-H $(C)$, and phosphorylated NF-M $(D)$, viewed under fluorescence. The sections were taken at the level shown in Figure $1 C$. Scale bar in $D$ is for all panels:

ence of labeled optic fibers in the uninjured contralateral nerve at 6,9 , and $12 \mathrm{~d}$. The misrouted axons were detected for the first time at $12 \mathrm{~d}(1$ animal). This was near the time regenerating axons that project normally are first detectable within the contralateral optic tract (Zhao and Szaro, 1994). At $12 \mathrm{~d}$, the misrouted axons were confined to the most distal regions of the contralateral optic nerve, near the chiasm. By $15 \mathrm{~d}$ after the surgery (two animals), and from then on for at least the next 20 $\mathrm{d}$ (three animals each were examined at 18,21, 28, and $35 \mathrm{~d}$ after the surgery), the misrouted axons were detected throughout the entire length of the contralateral optic nerve. For example, Figure 2 shows misrouted axons in a frog, $21 \mathrm{~d}$ after surgery. As also reported by Fawcett (1985), the misrouted axons were distributed around the periphery of cross-sections of the contralateral optic nerve and were segregated from the resident population of normally projecting axons. The misrouted axons could be traced throughout the entire length of the nerve (Fig. $2 A-C$ ) into the contralateral eye (Fig. 2D).
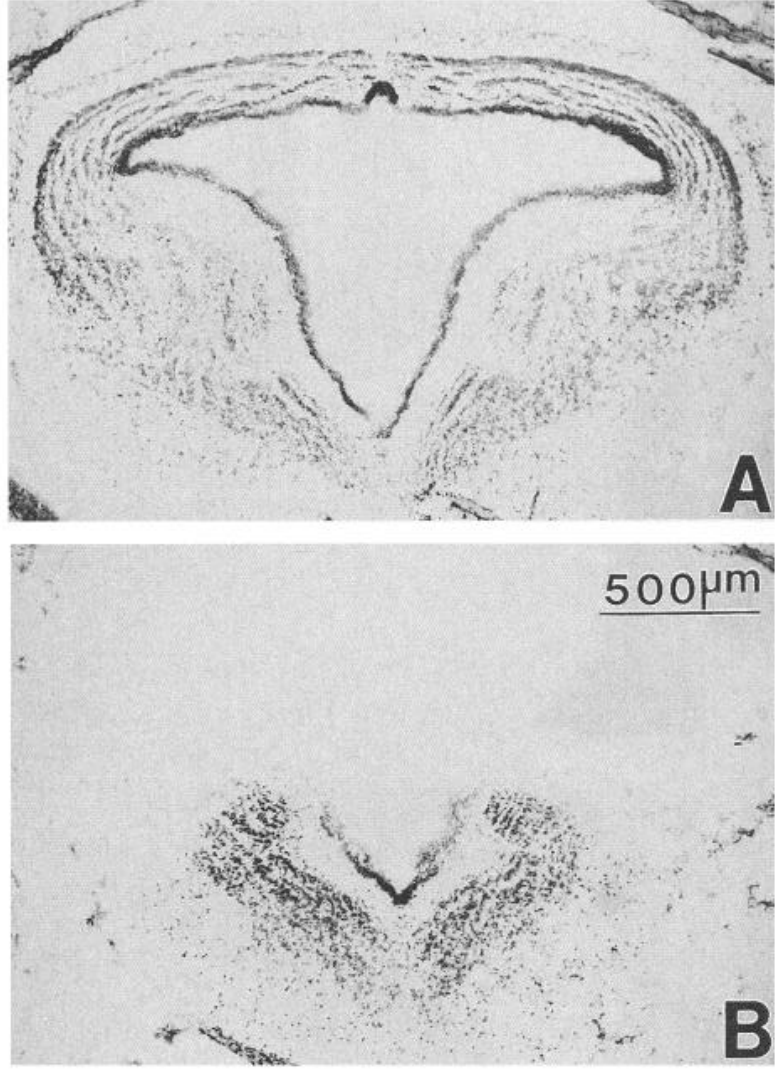

Figure 6. Transversely cut cross sections through the middle of the optic tecta from a normal frog $(A)$ and from one whose optic tecta were ablated $(B)$. The sections were stained with cresyl violet. The magnification is the same for both $A$ and $B$.

Previously, the emergence of XNIF, NF-L, and phosphorylation independent NF-M (NF-M/ind) was found to coincide with the entry of regenerating axons into the optic chiasm at $9 \mathrm{~d}$ after surgery. After $12 \mathrm{~d}$, the expression of these neurofilament proteins increased as axons extended into the optic tract. The emergence of phosphorylated NF-M (NF-M/P) and nonphosphorylated NF-H coincided with the arrival of axons at the optic tectum between 15 and $21 \mathrm{~d}$ (Zhao and Szaro, 1994). An example of normally regenerating axons within the crushed optic nerve, $35 \mathrm{~d}$ after axotomy is shown in Figure 3. These axons were stained in serial sections with antibodies to NF-M/ind, NF-M/P, and NF-H (Fig. 3A-C, respectively). The immunostained regenerating axons were distributed along the glial limitans of the nerve in cross-section. The unstained core of the cross-section contained degenerating fibers and astrocytic cell bodies.

The neurofilament composition of retinoretinal axons of the contralateral nerve was examined between 21 and $35 \mathrm{~d}$ after axotomy (three animals each at 21,28 , and $35 \mathrm{~d}$ ), with similar results at each time point. Figure 4 shows examples of retinoretinal axons of the contralateral nerve, $35 \mathrm{~d}$ after axotomy. These pictures of neurofilament staining are from the same sections as those shown in Figure 3. The misrouted retinoretinal axons were identified by the dense staining with WGA-HRP (Fig. 4A). These same axons, shown in the adjacent section (Fig. $4 B$ ), were poorly stained by the antibody to NF-M/ind, compared to the normal, uninjured axons of the contralateral eye within the same nerve and to axons of the crushed nerve from the same section (Fig. 3A). Similarly, immunostainings of XNIF 

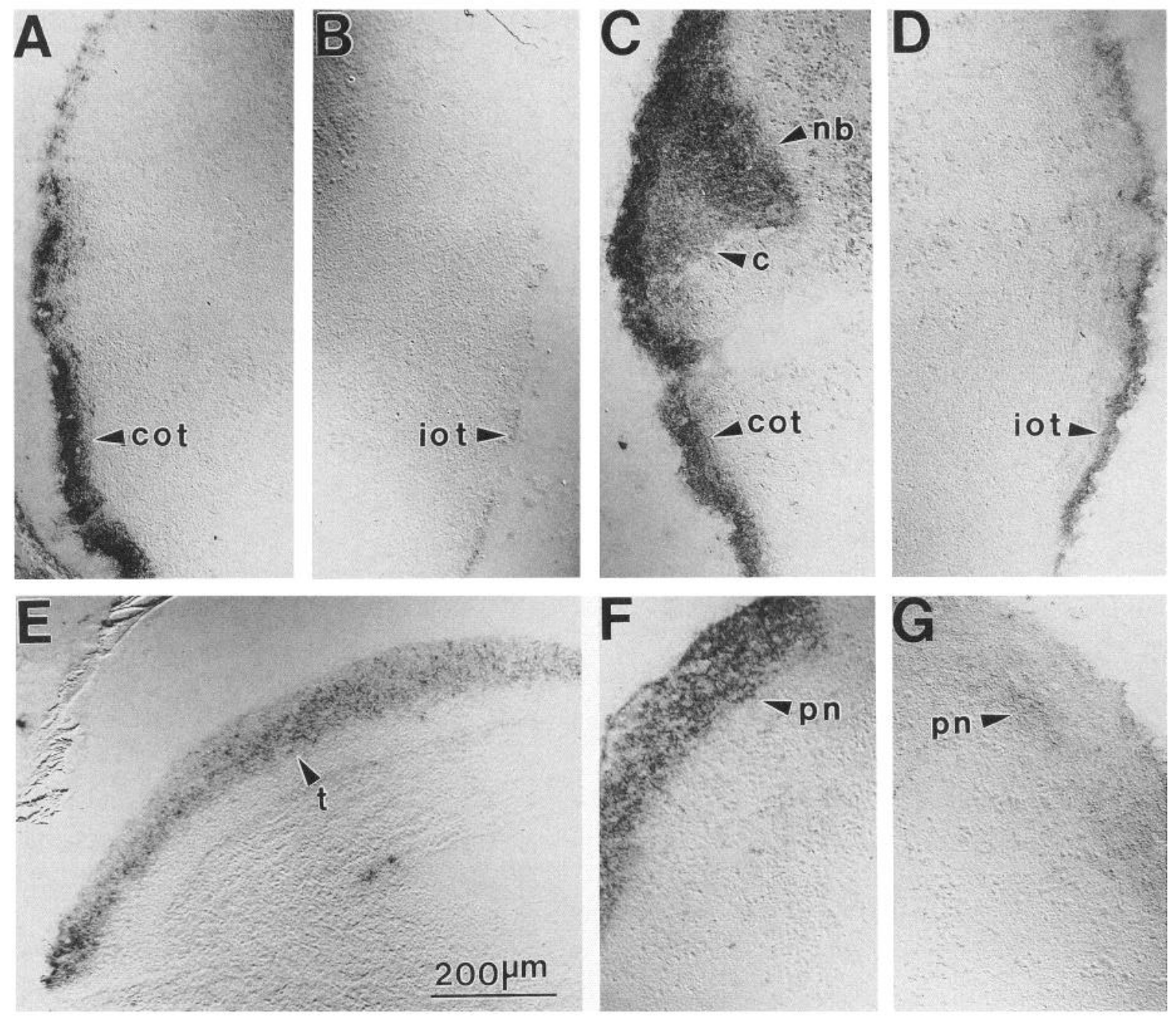

Figure 7. Projection of the regenerating optic axons of a tecta-ablated animal $(C, D, F, G)$ as compared to that of a sham-operated control animal $(A, B, E), 3$ weeks after surgery. The regenerating optic axons were labeled by intraocular injection of WGA-HRP. Sections were cut transversely. Lateral is to the left in $A, C, E, F$ and to the right in $B, D, G$. Dorsal is up in all panels. $A$, Labeled regenerating optic axons within the contralateral optic tract $(c o t)$ in a sham-operated control animal. B, Labeled regenerating optic axons within the ipsilateral optic tract (iot) on the same section as shown in $A$. $C$, Labeled regenerating optic axons within the contralateral optic tract $(c o t)$, the nucleus Bellonci $(n b)$, and the corpus geniculatum thalamicum $(c)$ in a tecta-ablated animal. $D$. Labeled regenerating optic axons within the ipsilateral optic tract (iot) on the same section as shown in $C$. $A-D$ are taken from approximately the level illustrated in Figure $1 C$. E, Labeled regenerating optic axons within the contralateral optic tectum $(t)$ in the sham-operated, control animal. This section was taken at approximately the level shown in Figure $1 D$. $F$ and $G$, Labeled regenerating optic axons within the posterior thalamic/pre-tectal nuclei $(p n)$ on both the contralateral $(F)$ and the ipsilateral $(G)$ sides of the tecta-ablated animal. These views are from sections located slightly rostral to those shown in Figure $1 D$ and panel $E$. Scale bar in $E$ is for all panels.

and NF-L were also reduced (not shown). In addition, the retinoretinal axons were completely unstained by antibodies to NF-H and NF-M/P (Fig. 4C,D, respectively). The density of labelling of these axons by WGA-HRP within the aberrant projection was equivalent to that seen in the normally regenerating optic nerve. Thus, the reduced staining by neurofilament antibodies was due to a reduction in the quantity of neurofilament proteins rather than in the number of axons. This observation is similar to that previously reported for normally regenerating optic axons prior to their arrival at the optic tract (Zhao and Szaro, 1994). In that study, this conclusion was verified by electron microscopy.

Moreover, it could be shown that the reduction in neurofilament epitopes was not caused by the increased distance of the cross-sections of retinoretinal axons from the eye, because segments of normally projecting axons within the optic tract were readily stained by all of the neurofilament antibodies by $28 \mathrm{~d}$ and from then on. These axons were 1.3-1.9 mm from the optic chiasm, whereas those shown in the retinoretinal projection of the contralateral nerve were $1.3 \mathrm{~mm}$ from the chiasm. Figure 5 shows an example of normally projecting axons labeled by WGA-HRP and by antibodies to NF-M/ind, NF-H, and NF-M/P (Fig. 5A-D, respectively), within the optic tract $28 \mathrm{~d}$ after axotomy.

\section{Changes in neurofilament protein composition after tectal ablation}

The retinoretinal axons encountered neither the optic tract nor their targets in the optic tectum, and had reduced levels of all neurofilament epitopes. By surgically ablating both optic tecta, it was possible to separate the effects of the tract from those of the tectum. Regenerating axons of tecta-ablated frogs enter the 

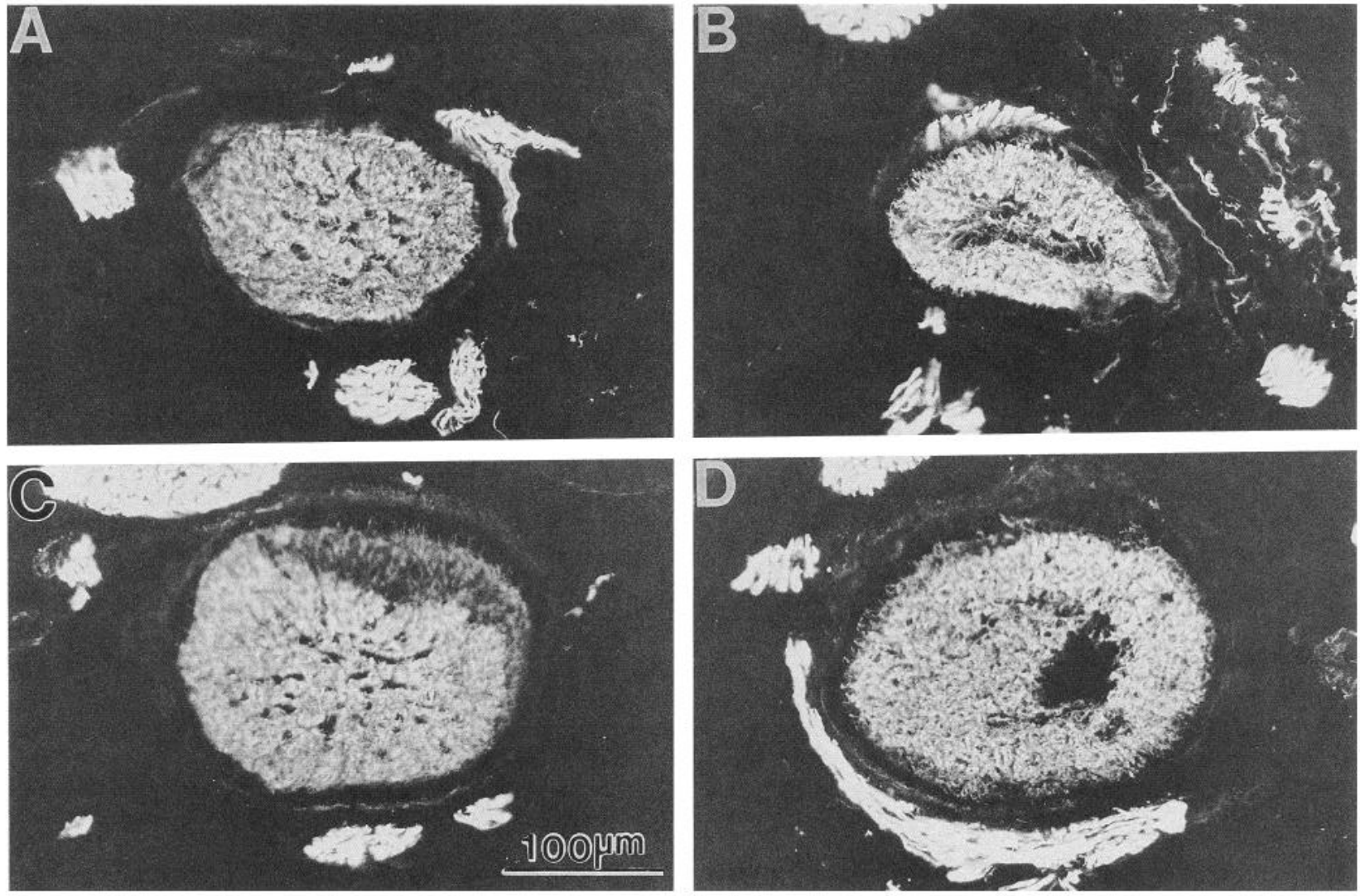

Figure 8. Anti-NF-M/ind (XC10C6) immunofluorescent staining of the uncrushed $(A)$ and regenerating, crushed $(B)$ optic nerves of a shamoperated, control animal, as compared to those of a tecta-ablated animal ( $C$, uncrushed; $D$, regenerating), 4 weeks after surgery. The sections were taken from a level near that shown in Figure $1 B$. Scale bar in $C$ is for all panels.

optic tract normally, but must seek alternative targets within the brain. To properly remove the targets of the regenerating axons it was necessary to ablate both tecta completely, since in several pilot trials, we determined that unilateral (one animal, analyzed $21 \mathrm{~d}$ after surgery) or incomplete bilateral (two animals, analyzed at 21 and 28 d after surgery) tectal ablation allowed large numbers of regenerating axons to innervate the remainder of the tectal lobes. Moreover, some of the axons in these animals expressed NF-M/P and NF-H. Thus for the rest of the animals in this study, we confirmed the success of tectal ablation by examining cresyl violet-stained sections cut through the midbrain. Such an example is shown in Figure $6 B$, as compared to a normal tectum in Figure $6 \mathrm{~A}$. Animals with portions of either tectum remaining intact were dropped from the study.

Bilateral tectal ablation induced dramatic changes in the innervation of targets by the regenerating axons. For example, Figure 7 compares the normal pathway taken by regenerating axons in a sham-operated control animal, $21 \mathrm{~d}$ after its optic nerve was crushed (Fig. $7 A, B, E$ ), to the pathway taken by regenerating axons in a tecta-ablated frog (Fig. $7 C, D, F, G$ ). In sham-operated controls, regenerating axons normally entered the contralateral optic tract (Fig. 7A) and innervated the contralateral optic tectum (Fig. $7 E$ ), and very few regenerating fibers were detected in the ipsilateral tract (Fig. 7B). In tecta-ablated frogs, more axons invaded the ipsilateral side (e.g., the ipsilateral optic tract in Fig. $7 D$ and the ipsilateral pretectal nucleus in Fig. $7 G$ ). Furthermore, regenerating axons entered deeper regions of the contralateral thalamus, such as the nucleus Bellonci, the corpus geniculatum thalamicum (Fig. $7 C$ ), and the pretectal nucleus (Fig. $7 F$ ).

The neurofilament composition of the optic nerves was determined immunocytochemically in sections adjacent to those stained by WGA-HRP. Tecta-ablated frogs were compared to sham-operated controls at 21 (three pairs of animals), 28 (three pairs of animals), and 42 (two pairs of animals) d after surgery. Each tecta-ablated frog was a co-reared sibling of its paired sham-operated control, and each was operated on the same day and processed in parallel with the other. In sham-operated control frogs, axons regenerating distal to the nerve crush expressed all neurofilament epitopes within $21 \mathrm{~d}$ after surgery (see also, Zhao and Szaro, 1994). By $28 \mathrm{~d}$, the staining of these epitopes was as intense in the regenerating nerves as it was in the uninjured axons of the contralateral nerve (NF-M/ind, Fig. $8 A, B$; NF-M/P, Fig. 9A,B; NF-H, Fig. $10 A, B$ ). In tecta-ablated frogs, staining with antibodies to NF-M/ind (Fig. $8 C, D$ ), NF-L, and XNIF (not shown) had also recovered by $28 \mathrm{~d}$, but staining with antibodies to NF-M/P and NF-H was significantly reduced from that of sham-operated controls. At $28 \mathrm{~d}$, staining by the antibody to NF-M/P was extremely faint in regenerating axons of tectaablated frogs (Fig. 9D) and that of NF-H was undetectable (Fig. $10 D$ ). [Note that in the animal shown in Figs. 9 and 10, one can see that the conditions of immunostaining in the tecta-ablated frogs matched those of the sham-operated control by comparing the intensity of staining of the surrounding extraocular axons (at arrowheads labeled pn), which were unaffected by the tectal surgery.] 

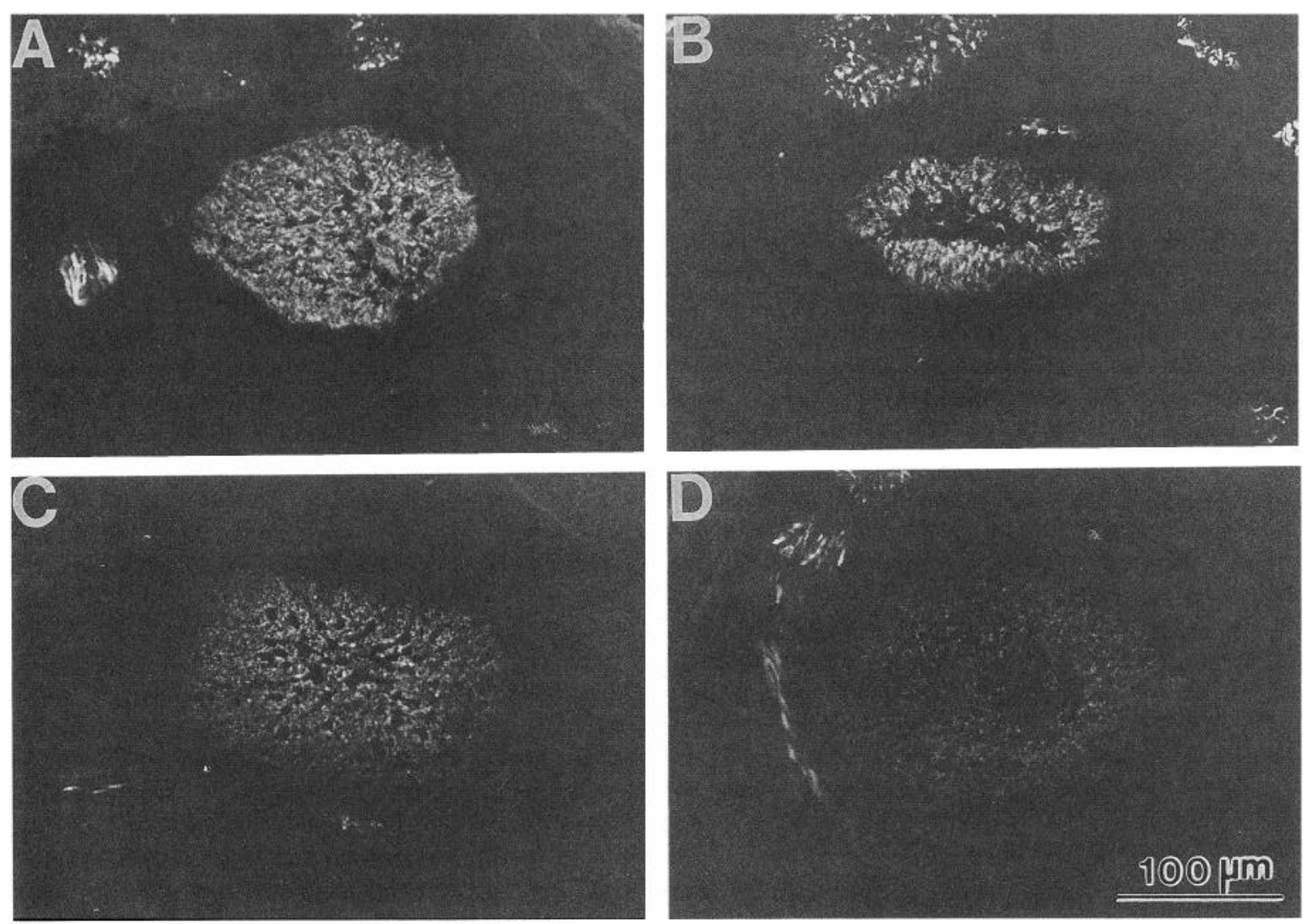

Figure 9. Sections taken from the same animals, and neighboring those shown in Figure 8, but stained with the monoclonal antibody (H053) directed against NF-M/P. $A$ and $B$ show the uncrushed and regenerating crushed nerves, respectively, of the sham-operated control; and $C$ and $D$ show the comparable sections of the tecta-ablated animal. Scale bar in $D$ is for all panels.

The argument that tectal ablation reduced the levels of NF$\mathrm{M} / \mathrm{P}$ and NF-H was further supported by staining of the optic nerve contralateral to the crush. These axons were also deprived of their normal targets by tectal ablation but were otherwise uninjured. In these axons, levels of NF-M/P (Fig. 9C) and NF-H (Fig. $10 \mathrm{C}$ ) were intermediate between those of their contralateral crushed nerve (Figs. $9 D, 10 D$ ) and of either crushed or uncrushed nerves in sham-operated controls (Figs. 9A,B;10A,B). Thus, removal of the target could by itself reduce the level of these epitopes in segments of axon that otherwise lacked any history of injury. As in the regenerating nerves, levels of NF$\mathrm{M} /$ ind at $28 \mathrm{~d}$ were unaffected by tectal ablation alone (Fig. $8 C$ ).

At $42 \mathrm{~d}$, levels of NF-H and NF-M/P remained much lower in the regenerating nerves of tecta-ablated frogs (Fig. 11B,D, respectively) than in sham-operated controls (Fig. $11 A, C$ ). However, for the first time, the NF-H epitope was detectable. Thus tectal ablation appeared to delay the expression of NF-H and NF-M/P rather than abolish it entirely.

\section{Discussion}

We conclude that the visual pathway directly influences the neurofilament protein composition of regenerating optic axons of Xenopus laevis. In normally regenerating axons, levels of XNIF, $\mathrm{NF}-\mathrm{L}$, and NF-M/ind increase following $9 \mathrm{~d}$ after axotomy; and NF-M/P and NF-H normally reappear at 15 and $18-21 \mathrm{~d}$, respectively. The effects seen on individual neurofilament epitopes differed between the retinoretinal axons, which fail to enter the optic tract and which innervate the contralateral eye instead of the tectum, and regenerating axons of tecta-ablated frogs, which enter the tract normally but are deprived of their usual targets. In the aberrant retinoretinal projection, the levels of all neurofilament epitopes remained depressed at all time points that were examined. In tecta-ablated frogs, regenerating axons had reduced levels of NF-H and NF-M/P but normal levels of XNIF, NF-L, and NF-M/ind. This shows that the sustained increase in the expression of XNIF, NF-L, and NF-M/ind that is found in normally regenerating axons must depend on cues from the optic tract, whereas the phosphorylation of NF-M and the expression of NF-H are influenced by cues encountered in the tectum. The differential effects on neurofilament epitopes also help to obviate criticisms that misrouted axons in this study were generally defective.

Although a number of axonal proteins are influenced by target and pathway interactions (e.g., Benowitz et al., 1981; Perry et al., 1990; Hieber et al., 1992), the placement of neurofilament proteins in this category is especially interesting, since they are believed to contribute to axonal stability. The progressive changes that occur in the molecular composition of neurofilaments during axonal growth may be responsible for gradually increasing the stability of developing axons (see also Fliegner et al., 1994; Lee and Cleveland, 1994). In growing axons, whose neurofilaments are characterized by the absence of NF-H and phosphorylated NF-M, the immature neurofilaments may enhance axonal stability without fully consolidating the cytoskeleton. This would facilitate elongation without inhibiting further growth. Such a role for neurofilaments in growing axons is supported by experiments in which neurofilament antibodies injected into Xenopus embryos produce somatic accumulations of 

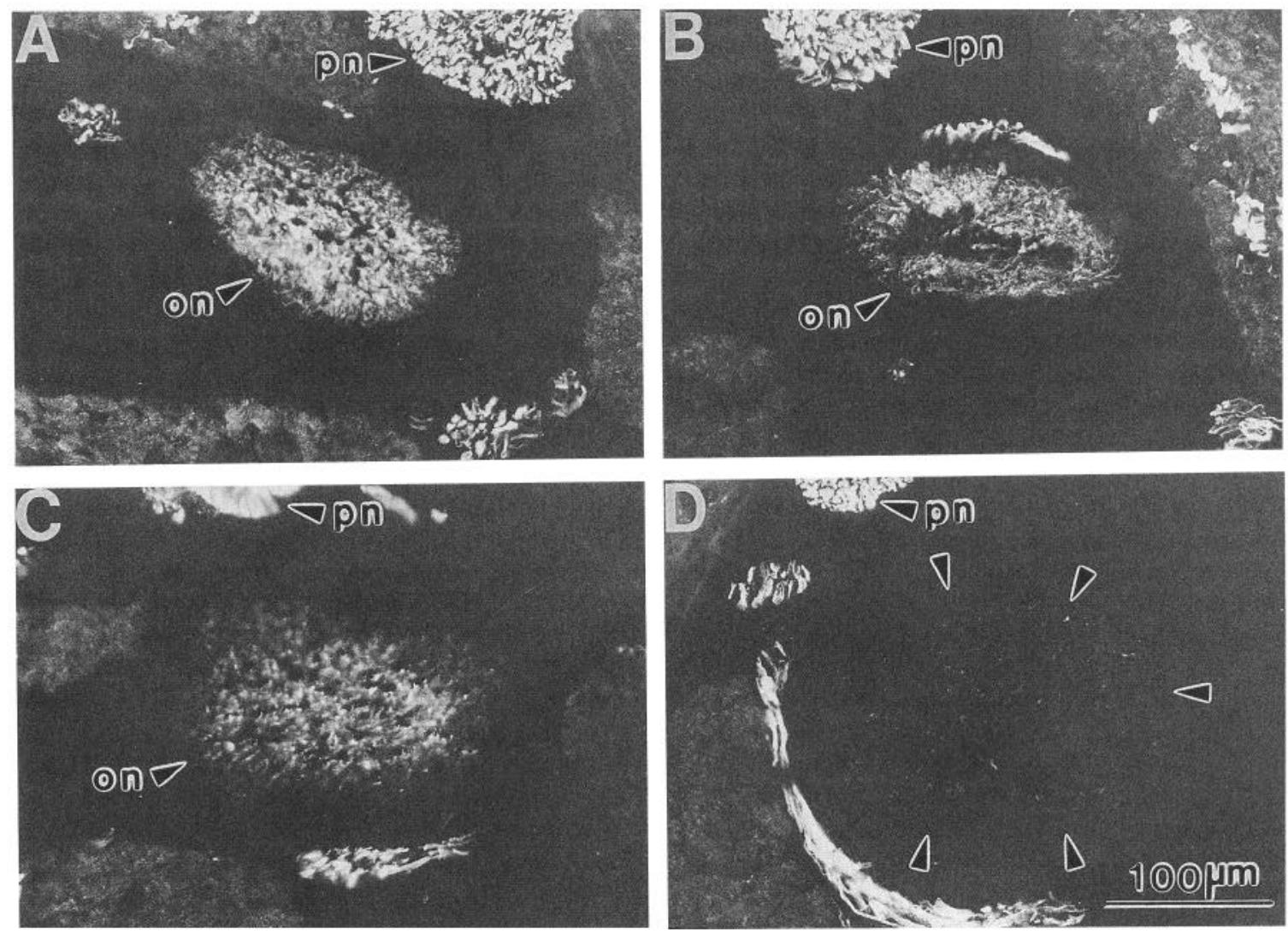

Figure 10. Sections stained with the antibody (DP-1) directed against non-phosphorylated NF-H, taken from the same animals and neighboring those shown in Figures 8 and 9. The uncrushed and regenerating crushed nerves of the sham operated control are shown in $A$ and $B$, respectively; and comparable views from a tectal ablated animal are shown in $C$ and $D$. The unlabeled arrowheads in $D$ point to the outer circumference of the otherwise unstained optic nerve. The arrowheads labeled on point to the optic nerves in $A-C$, whereas the arrowheads labeled pn point to neighboring peripheral nerves in all panels. Scale bar in $D$ is for all panels.

neurofilaments and significantly inhibit the extent of axonal outgrowth achieved by stage 39/40 (Szaro et al., 1991). In adult myelinated peripheral axons, the neurofilaments are the principal determinant of axonal caliber (Friede and Samorajski, 1970; Hoffman et al., 1984, 1987; Muma et al., 1991; Eyer and Peterson, 1994). Although increases in neurofilament number appear to drive the postnatal growth in axonal caliber, the effect appears to involve changes in the composition of neurofilaments as well (Cleveland et al., 1991). The addition of NF-H to axonal neurofilaments, which coincides postnatally with the increases in axonal caliber, may be the critical factor (Lee and Cleveland, 1994). This special role for NF-H is probably mediated through its uniquely long carboxyl terminal domain, which forms extensive cross-bridges between adjacent neurofilaments (Hirokawa et al., 1984). These cross-bridges become extensively phosphorylated over time, which dissociates neurofilaments from microtubules (Hisanaga et al., 1991), thereby decelerating the rates of slow axonal transport (Nixon and Logivenko, 1986; Nixon et al., 1987; de Waegh et al., 1991; Nixon and Sihag, 1991). Increased phosphorylation of NF-H also correlates with larger numbers of extensively cross-linked neurofilaments (Szaro et al., 1990; Gotow and Tanaka, 1994) and thus may help drive the increases in axonal caliber (de Waegh et al., 1992). NF-M also contains a multiply phosphorylated carboxyl terminal domain, but less is known about its function. The projections made by the carboxyl domain of NF-M are shorter and interact less extensively with other neurofilaments than do those of NF-H (Go- tow et al., 1992). Nevertheless, increases in NF-M phosphorylation are also associated with axonal maturation (Carden et al., 1987; Szaro et al., 1989) and decelerated rates of slow axonal transport (de Waegh et al., 1992). Possibly, NF-M phosphorylation modulates neurofilament transport at earlier developmental stages when NF-H is absent, but consolidates the neurofilaments less effectively than NF-H does when it is present.

If neurofilaments do indeed stabilize axons, the paucity of neurofilaments in the retinoretinal projection has important implications, because the retinoretinal projection is unstable (Tennant et al., 1993; Bohn and Stelzner, 1981a). The number of axons in this projection reaches a maximum by 6 weeks after axotomy, and they disappear entirely by 24 weeks. One possibility is that the instability of the retinoretinal projection results directly from the prolonged immaturity of the neurofilaments in these axons. If so, then establishing how pathways and targets influence neurofilaments will be important for understanding the instability of this and other transient projections.

Driving axonal stability through progressive changes in neurofilament composition would necessitate that neurons coordinate neurofilament composition with the progress of axonal growth. This could be accomplished by having the neuron mark time after axotomy, or more effectively, by directly coupling neurofilament expression with external cues encountered by regrowing axons (for further discussion of this issue, see for example, Schwarz et al., 1990). Our results provide compelling evidence that the latter is the case in regenerating Xenopus optic 

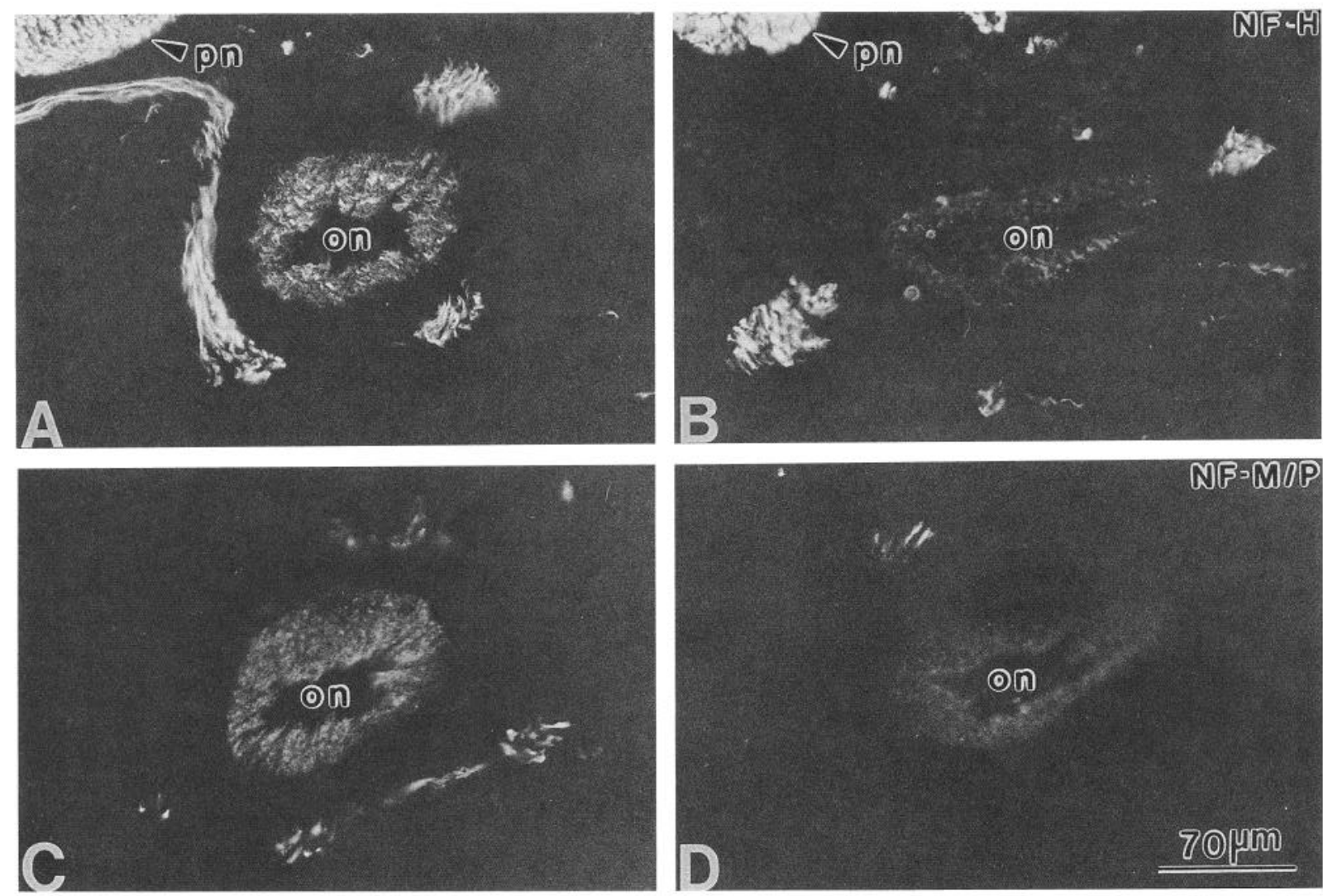

Figure 11. Regenerating, crushed optic nerves (on) from a sham operated control $(A$ and $C$ ) and a tectal ablated $(B$ and $D)$ frog, 6 weeks after surgery. The sections in $A$ and $B$ were stained with the antibody directed against NF-H (DP-1), whereas those in $C$ and $D$ were stained with the antibody to NF-M/P (H053). $A$ and $C$, and $B$ and $D$ represent two pairs of serial sections, respectively. The arrowheads labeled pn point to adjacent peripheral nerves. Scale bar in $D$ is for all panels.

nerves. Previous studies have shown that the neurofilament compositions of axons can be modulated by a variety of external factors. For example in rats, preventing regenerating sensory axons from encountering the spinal cord prevents the usual increase in NF-L, -M, and - $\mathrm{H}$ expression that normally occurs when these axons enter the spinal cord (Liuzzi and Tedeschi, 1992). Experiments with trembler mice have shown that myelination stimulates increases in the phosphorylation of NF-M and -H locally within the nerve (de Waegh et al., 1992). Similarly, transgenic hypomyelinating mice show decreases in the phosphorylation of NF-H and in axonal caliber caused by a lack of myelination from Schwann cells (Cole et al., 1994). In chicken embryos, a phosphorylated epitope of NF-M emerges locally within developing axons at positions where previous experiments suggested that axons begin to respond to specific guidance cues (Landmesser and Swain, 1992). And in goldfish, whose optic nerve contains unique neurofilament proteins that are modulated during regeneration (Quitschke and Schechter, 1983, 1986; Tesser et al., 1986; Glasgow et al., 1992), the expression of one of these $\left(\mathrm{ON}_{1}\right)$ increases after the arrival of axons at the tectum. Ablation of the tecta prior to placing retinal ganglion cells into culture results in a more rapid decline in $\mathrm{ON}_{1}$ synthesis than from cultured cells of normal goldfish (Hall and Schechter, 1991). Our results in Xenopus regenerating optic axons extend these observations by directly demonstrating in situ that separate portions of the visual pathway influence the progressive maturation of neurofilaments. Thus neurofilament proteins could offer us a molecular focus for studying the intracellular responses of axons to external cues.

The reemergence of NF-H and NF-M/P occurs after axons arrive at the tectum, but prior to the restoration of a retinotopic map (Fawcett, 1985; Szaro et al., 1985; Zhao and Szaro, 1994). Tectal cues could therefore include soluble growth factors, contact with specific neurons, glial cells or extracellular matrix components, or the formation of test synapses. Currently, all seem equally likely. The faint staining of NF-H and NF-M/P seen at $42 \mathrm{~d}$ in tecta-ablated frogs (Fig. 11) suggests that not all of the factors that influence the return of these epitopes are unique to the tectum. Pretectal areas that normally receive direct optic input may also be capable of providing sufficient cues. Alternatively, the optic nerve and tract may directly inhibit the emergence of these epitopes until growth cones arrive at potentially suitable targets.

Whatever the cues, because they can affect neurofilament proteins separately, they must act through different pathways. Molecular evidence for multiple potential regulatory mechanisms is mounting. In mammals, NF-L appears to be regulated at both transcriptional and posttranscriptional levels (Nakahira et al., 1990; Beaudet et al., 1992, 1993; Ivanov and Brown, 1992; Reeben et al., 1993; Yazdanbakhsh et al., 1993). The decline of NF-L mRNA that follows axotomy (Goldstein et al., 1988) results from an actinomycin-sensitive destabilization of mRNA (Schwartz et al., 1992). The promoter of the NF-L gene shares some of its potential regulatory sequences with NF-M (Ivanov 
and Brown, 1992), and the promoters of both NF-H (Elder et al., 1992a) and NF-M (Elder et al., 1992b) contain additional novel potential regulatory sites. Moreover, the factors that are responsible for neurofilament phosphorylation have begun to be identified. More than one mammalian neurofilament kinase exists (Hellmich et al., 1992; Lew et al., 1992; Xiao and Monteiro, 1994), and a neurofilament kinase regulatory protein has been identified (Ishiguro et al., 1994; Lew et al., 1994; Tsai et al., 1994). Although similar elements remain to be identified in Xenopus, our results suggest a biological rationale for the existence of so many different molecular regulatory factors.

\section{References}

Beaudet LF, Charron G, Houle D, Tretjakoff I, Peterson A, Julien J-P (1992) Intragenic regulatory elements contribute to transcriptional control of the neurofilament light gene. Gene 116:205-214.

Beaudet LF, Cote F, Houle D, Julien J-P (1993) Different posttranscriptional controls for the human neurofilament light and heavy genes in transgenic mice. Mol Brain Res 18:23-31.

Benowitz LI, Shashoua VE, Yoon MG (1981) Transported proteins in the regenerating optic nerve: regulation by interactions with the optic tectum. Science 222:185-188.

Bohn RC, Stelzner DJ (1979) Aberrant retino-retinal pathway during early stages of regeneration in adult Rana pipiens. Brain Res 160: 139-144.

Bohn RC, Stelzner DJ (1981a) The aberrant retino-retinal projection during optic nerve regeneration in the frog. I. Time course of formation and cells of origin. J Comp Neurol 196:605-620.

Bohn RC, Stelzner Df (1981b) The aherrant retino-retinal projection during optic nerve regeneration in the frog. II. Anterograde labeling with horseradish peroxidase. J Comp Neurol 196:621-632.

Bohn RC, Stelzner DJ (1981c) The aberrant retino retinal projection during optic nerve regeneration in the frog. III. Effects of crushing both nerves. J Comp Neurol 196:633-643.

Carden MJ, Trojanowski JQ, Schlaepfer WW, Lee VM-Y (1987) Twostage expression of neurofilament polypeptides during rat neurogenesis with early establishment of adult phosphorylation patterns. $\mathbf{J}$ Neurosci 1:3489-3504.

Charnas LR, Szaro BG, Gainer H (1992) Identification and developmental expression of a novel low molecular weight neuronal intermediate filament protein expressed in Xenopus laevis. J Neurosci 12: 3010-3024.

Cleveland DW, Monteiro M.J, Wong PC, Gill SR, Gearhart JD, Hoffman PN (1991) Involvement of neurofilaments in the radial growth of axons. J Cell Sci [Suppl] 15:85-95.

Cole JS, Messing A, Trojanowski JQ, Lee VM-Y (1994) Modulation of axon diameter and neurofilaments by hypomyelinating Schwann cells in transgenic mice. J Neurosci 14:6956-6966.

Dahl D, Bignami A (1986) Neurofilament phosphorylation in development: a sign of axonal maturation? Exp Cell Res 162:220-230.

Dahl D, Crosby CJ, Gardner EE, Bignami A (1986) Delayed phosphorylation of the largest neurofilament protein in rat optic nerve development. J Neurosci Res 15:513-519.

Dahl D, Labkovsky B, Bignami A (1989) Early and late appearance of neurofilament phosphorylation events in nerve regeneration. Brain Res Bull 22:225-232.

de Waegh SM, Brady ST (1991) Local control of axonal properties by Schwann cells: neurofilaments and axonal transport in homologous and heterologous nerve grafts. J Neurosci Res 30:201-212.

de Waegh SM, Lee VM-Y, Brady ST (1992) Local modulation of neurofilament phosphorylation, axonal caliber, and slow axonal transport by myelinating Schwann cells. Cell 68:451-463.

Elder GA, Liang Z, Lee N, Friedrich VL Ji, Lazzarini RA (1992a) Novel DNA binding proteins participate in the regulation of human neurofilament $\mathrm{H}$ gene expression. Mol Brain Res 15:85-98.

Elder GA, Liang Z, Snyder SE, Lazzarini RA (1992b) Multiple nuclear factors interact with the promoter of the human neurofilament $M$ gene. Mol Brain Res 15:99-105.

Eyer J, Peterson A (1994) Neurofilament-deficient axons and perikaryal aggregates in viable transgenic mice expressing a neurofilamentbeta-galactosidase fusion protein. Neuron 12:389-405.

Fawcett JW (1985) Factors guiding regenerating retinotectal fibres in the frog Xenopus laevis. J Embryol Exp Morphol 90:233-250.
Fliegner KH, Kaplan MP, Wood TL, Pintar JE, Liem RKH (1994) Expression of the gene for the neuronal intermediate filament protein alpha-internexin coincides with the onset of neuronal differentiation in the developing rat nervous system. J Comp Neurol 342:161-173.

Friede RL, Samorajski T (1970) Axon caliber related to neurofilaments and microtubules in sciatic nerve fibers of rats and mice. Anat Rec $16 \%: 379-388$.

Glasgow E, Druger RK, Levine EM, Fuchs C, Schechter N (1992) Plasticin, a novel type III neurofilament protein from goldfish retina: increased expression during optic nerve regeneration. Neuron 9:373381.

Goldstein ME, Cooper HS, Bruce J, Carden MJ, Lee VM-Y, Schlaepfer WW (1987) Phosphorylation of neurofilament proteins and chromatolysis following transection of rat sciatic nerve. J Neurosci 7:1586-1594.

Goldstein ME, Weiss SR, Lazzarini RA, Shneidman PS, Lees JF, Schlaepfer WW (1988) mRNA levels of all three neurofilament proteins decline following nerve transection. Mol Brain Res 3:287-292.

Gotow T, Tanaka J (1994) Phosphorylation of neurofilament $\mathrm{H}$ subunit as related to arrangement of neurofilaments. J Neurosci Res 37:691713.

Gotow T, Takeda M, Tanaka T, Hashimoto PH (1992) Macromolecular structure of reassembled neurofilaments as revealed by the quickfreeze deep-etch mica method: difference between NF-M and NF-H subunits in their ability to form cross-bridges. Eur $\mathrm{J}$ Cell Biol 58: 331-345.

Hall CM, Schechter N (1991) Expression of neuronal intermediate filament proteins $\mathrm{ON}_{1}$ and $\mathrm{ON}_{2}$ during goldfish optic nerve regeneration: effect of tectal ablation. Neuroscience 41:695-701.

Hellmich MR, Pant HC, Wada E, Battey JF (1992) Neuronal cdc2-like kinase: a cdc2-related protein kinase with predominantly neuronal expression. Proc Natl Acad Sci USA 89:10867-10871.

Hieber V, Agranoff BW, Goldman D (1992) Target-dependent regulation of retinal nicotinic acetylcholine receptor and tubulin RNAs during optic nerve regeneration in goldfish. $\mathbf{J}$ Neurochem 58:1009-1015.

Hirokawa N, Glicksman MA, Willard MB (1984) Organization of mammalian neurofilament polypeptides within the neuronal cytoskeleton. J Cell Biol 98:1523-1536.

Hisanaga S, Kusubata M, Okumura E, Kishimoto T (1991) Phosphorylation of neurofilament $\mathrm{H}$ subunit at the tail domain by cdc2 kinase dissociates the association to microtubules. J Biol Chem 266:2179821803.

Hoffman PN, Griffin JW, Price DL (1984) Control of axonal caliber by neurofilament transport. J Cell Biol 99:705-714.

Hoffman PN, Cleveland DW, Griffin JW, Landes PW, Cowan NJ, Price DL (1987) Neurofilament gene expression: a major determinant of axonal caliber. Proc Natl Acad Sci USA 84:3472-3476.

Hoperskaya OA (1975) The development of animals homozygous for a mutation causing periodic albinism $\left(\mathrm{a}^{\mathrm{p}}\right)$ in Xenopus laevis. $\mathrm{J}$ Embryol Exp Morphol 34:253-264.

Humphrey MF, Beazley LD (1985) Retinal ganglion cell death during optic nerve regeneration in the frog Hyla moorei. J Comp Neurol $236: 382-402$.

Ishiguro K, Kobayashi S, Omori A, Takamatsu M, Yonakura S, Anzai $\mathrm{K}$, Imahori K, Uchida T (1994) Identification of the $23 \mathrm{kDa}$ subunit of tau protein kinase II as a putative activator of cdk5 in bovine brain. FEBS Lett 342:203-208.

Ivanov TR, Brown IR (1992) Interaction of multiple nuclear proteins with the promoter region of the mouse $68-\mathrm{kDa}$ neurofilament gene. J Neurosci Res 32:149-158.

Kaplan MP, Chin SS, Fliegner KH, Liem RK (1990) Alpha-internexin, a novel neuronal intermediate filament protein, precedes the low molecular weight neurofilament protein (NF-L) in the developing rat brain. I Neurosci 10:2735-2748.

Landmesser L, Swain S (1992) Temporal and spatial modulation of a cytoskeletal antigen during peripheral axonal pathfinding. Neuron 8:291-305.

Lee M, Xu Z, Wong P, Cleveland D (1993) Neurofilaments are obligate heteropolymers in vivo. J Cell Biol 122:1337-1350.

Lee MK, Cleveland DW (1994) Neurofilament function and dysfunction: involvement in axonal growth and neuronal disease. Curr Opinion Cell Biol 6:34-40

Lee VM-Y, Carden MJ, Trojanowski JQ (1986) Novel monoclonal antibodies provide evidence for the in situ existence of a non-phos- 
phorylated form of the largest neurofilament subunit. $\mathbf{J}$ Neurosci 6:850-858.

Lee VM-Y, Otvos L Jr, Carden MJ, Hollosi M, Dietzschold B, Lazzarini RA (1988) Identification of the major multi-phosphorylation site in mammalian neurofilaments. Proc Natl Acad Sci USA 85:1998-2002.

Lew J, Winkfein RJ, Paudel HK, Wang JH (1992) Brain proline-directed protein kinase is a neurofilament kinase which displays high sequence homology to p34cdc2. J Biol Chem 267:25922-25926.

Lew J, Huang Q-Q, Qi Z, Winkfein RJ, Aebersold R, Hunt T, and Wang JH (1994) A brain-specific activator of cyclin-dependent kinase 5. Nature 371:423-425.

Liuzzi FJ, Tedeschi B (1992) Axo-glial interactions at the dorsal root transitional zone regulate neurofilament protein synthesis in axotomized sensory neurons. J Neurosci 12:4783-4792.

Mikucki SA, Oblinger MM (1991) Corticospinal neurons exhibit a novel pattern of cytoskeletal gene expression after injury. J Neurosci Res 30:213-225.

Muma NA, Slunt HH, Hoffman PN (1991) Postnatal increases in neurofilament gene expression correlate with the radial growth of axons. J Neurocytol 20:844-854.

Nakahira K, Ikenaka K, Wada K, Tamura T, Firvich T, Mikoshiba K (1990) Structure of the $68 \mathrm{kDa}$ neurofilament gene and regulation of its expression. J Biol Chem 265:19786-19791.

Nixon RA, Logivenko KB (1986) Multiple fates of newly synthesized neurofilament proteins: evidence for a stationary neurofilament network distributed nonuniformly along axons of retinal ganglion cell neurons. J Cell Biol 102:647-659.

Nixon RA, Sihag RK (1991) Neurofilament phosphorylation: a new look at regulation and function. Trends Neurosei 14:501-506.

Nixon RA, Lewis SE, Marotta CA (1987) Posttranslational modification of neurofilament proteins by phosphate during axoplasmic transport in retinal ganglion cell neurons. J Neurosci 7:1145-1158.

Oblinger MM, Lasek RJ (1988) Axotomy-induced alterations in the synthesis and transport of neurofilaments and microtubules in dorsal root ganglion cells. J Neurosci 8:174-1758.

Oblinger MM, Szumlas RA, Wong J, Liuzzi FJ (1989) Changes in neurofilament gene expression affect the composition of regenerating axonal sprouts elaborated by DRG neurons in vivo. J Neurosci 9:2645-2653.

Pachter JS, Liem RKH (1984) The differential appearance of neurofilament triplet polypeptides in the developing rat optic nerve. Dev Biol 103:200-210.

Perry GW, Burmeister DW, and Grafstein B (1990) Effect of target removal on goldfish optic nerve regeneration: analysis of fast axonally transported proteins. J Neurosci 10:3439-3448.

Quitschke W, Schechter N (1983) Specific optic nerve proteins during regeneration of the goldfish retinotectal pathway. Brain Res 258:6978.

Quitschke W, Schechter N (1986) Homology and diversity between intermediate filament proteins of neuronal and nonneuronal origin in the goldfish optic nerve. J Neurochem 46:545-555.

Reeben M, Halmekyto M, Alhonen L, Sinervirta R, Saarma M, Janne
J (1993) Tissue-specific expression of rat light neurofilament promoter-driven reporter gene in transgenic mice. Biochem Biophys Res Commun 192:465-470.

Schwartz ML, Shneidman PS, Bruce J, Schlaepfer WW (1990) Axonal dependency of the postnatal upregulation in neurofilament expression. J Neurosci Res 27:193-201.

Schwartz ML, Shneidman PS, Bruce J, Schlaepfer WW (1992) Actinomycin prevents the destabilization of neurofilament mRNA in primary sensory neurons. J Biol Chem 267:24596-24600.

Shaw G, Weber K (1982) Differential expression of neurofilament triplet proteins in brain development. Nature 298:277-279.

Szaro BG, Gainer H (1988) Identities, antigenic determinants, and topographic distributions of neurofilament proteins in the nervous systems of adult frogs and tadpoles of Xenopus laevis. J Comp Neurol 273:344-358.

Szaro BG, Loh YP, Hunt RK (1985) Specific changes in axonally transported proteins during regeneration of the frog (Xenopus laevis) optic nerve. J Neurosci 5:192-208.

Szaro BG, Lee VM-Y, Gainer H (1989) Spatial and temporal expression of phosphorylated and non-phosphorylated forms of neurofilament proteins in the developing nervous systen of Xenopus laevis. Dev Brain Res 48:87-103.

Szaro BG, Whitnall MH, Gainer H (1990) Phosphorylation-dependent epitopes on neurofilament proteins and neurotilament densities differ in axons in the corticospinal and primary sensory dorsal column tracts in the rat spinal cord. J Comp Neurol 302:220-235.

Szaro BG, Grant P, Lee VM-Y, Gainer H (1991) Inhibition of axonal development after injection of neurofilament antibodies into a Xenopus laevis embryo. J Comp Nenrol 308:576-585.

Tennant M, Bruce SR, Beazley LD (1993) Survival of ganglion cells which form the retino-retinal projection during optic nerve regeneration in the frog. Visual Neurosci 10:681 686.

Tesser P, Jones PS, Schechter N (1986) Elevated levels of retinal neurofilament mRNA accompany optic nerve regeneration. $\mathbf{J}$ Neurochem 47:1235-1243.

Tompkins R (1977) Grafting analysis of the periodic albino mutant of Xenopus laevis. Proc Natl Acad Sci USA 76:4350-4354.

Tsai L-H, Delalle I, Caviness VS Jr, Chae T; Harlow E (1994) p35 is a neural-specific regulatory subunit of cyclin-dependent kinase 5 . Nature 371:419-422.

Wetzel DM, Lee VM-Y, Erulkar SD (1989) Long term cultures of neurons from adult frog brain express GABA and glutamate-activated channels. J Neurobiol 20:255-270.

Xiao J, Monteiro MJ (1994) Identification and characterization of a novel (115 kDa) neurofilament-associated kinase. J Neurosci 14: 18201833.

Yazdanbakhsh K, Fraser P, Kioussis D, Vidal M, Grosveld F, Lindenbaum M (1993) Functional analysis of the human neurofilament light chain gene promoler. Nucleic Acids Res 21:455-461.

Zhao Y, Szaro BG (1994) The return of phosphorylated and nonphosphorylated epitopes of neurofilament proteins to the regenerating optic nerve of Xenopus laevis. J Comp Neurol 343:158-172. 